\title{
ZONASI GEOMORFOLOGI DAN KOREKSI KOLOM AIR UNTUK PEMETAAN SUBSTRAT DASAR MENGGUNAKAN CITRA QUICKBIRD
}

\author{
(GEOMORPHOLOGY ZONATION AND COLUMN CORRECTION \\ FOR BOTTOM SUBSTRAT MAPPING USING QUICKBIRD IMAGE) \\ Muhammad Banda Selamat ${ }^{12}$, Indra Jaya, Vincentius P. Siregar, Totok Hestirianoto \\ ${ }^{1}$ Corresponding author \\ 2Jurusan Ilmu Kelautan Universitas Hasanuddin, Makassar \\ E-mail : mbandas2006@yahoo.com \\ ${ }^{3}$ Departemen Ilmu dan Teknologi Kelautan \\ Fakultas Perikanan dan Ilmu Kelautan IPB
}

\begin{abstract}
Bias may occur on attenuation coefficient ratio estimated from water column correction method. This bias then contribute to thematic accuracy of bottom substrate images. This study used geomorphologic spatial zonation to improve thematic accuracy of bottom substrate maps that produced from water column correction method. Quickbird pixel values were converted to the top of atmosphere radiance and followed by water column correction to make bottom substrate map with three themes i.e. sand, seagrass and coral reef. Field data were grouped using Bray Curtis method and become basis of image reclassification. Geomorphological profile was extracted from green and red composite images, refer to a bathymetric survey. This combined method was significantly reach the thematic accuracy up to more than $80 \%$.
\end{abstract}

Keywords : Quickbird, bottom subtrate, thematic accuracy

\begin{abstract}
ABSTRAK
Salah satu kelemahan metode koreksi kolom air adalah dapat memunculkan bias dalam estimasi rasio koefisien atenuasi. Bias ini berkontribusi pada nilai akurasi tematik peta substrat dasar. Studi ini menggunakan pendekatan zonasi geomorfologi untuk meningkatkan akurasi tematik peta substrat yang dihasilkan dari metode koreksi kolom air. Nilai piksel citra Quickbird dikonversi ke radiansi dan dilanjutkan dengan koreksi kolom air untuk menghasilkan peta substrat dasar dengan tiga tema: substrat dominan pasir, lamun dan karang. Data lapangan dikelompokkan menggunakan metode Bray curtis dan menjadi dasar bagi reklasifikasi. Profil geomorfologi dicitra disadap dari gabungan kanal hijau dan merah, mengacu pada hasil survei batimetri. Akurasi tematik metode kombinasi ini dapat mencapai lebih dari 80\%.
\end{abstract}

Kata kunci: Quickbird, substrat dasar, akurasi tematik

\section{PENDAhuluan}

Perencanaan spasial kelautan untuk zonasi kawasan pesisir yang multi fungsi sedang gencar dilakukan baik di negara maju maupun negara berkembang. Ketersediaan peta-peta sumberdaya yang komprehensif, termasuk yang diperlukan untuk pengelolaan sumberdaya perikanan lokal dan konservasi keanekaragaman hayati, menjadi informasi dasar yang krusial dalam proses perencanaan tersebut (Knudby, et al. 2011). Satelit penginderaan jauh memiliki kapasitas untuk meningkatkan pemahaman tentang habitat terumbu karang melalui penyediaan informasi yang secara spasial dan runtun waktu sangat relevan dengan upaya pengelolaan dan secara praktis tidak dapat diperoleh dari pengamatan insitu semata (Eakin, et al. 2010). Kemampuan satelit ini terkadang ditonjolkan secara berlebihan kepada para pengguna (Meaden dan Kapetsky, 1991). Sebagai akibatnya, sejumlah ahli ekologi karang terkadang sedikit berilusi didalam menerapkan teknologi ini kedalam permasalahan ekologi (Mumby et al., 1998).

Penyidikan lingkungan terumbu karang berdasarkan zonasi geomorfologi menjadi salah satu aplikasi penginderaan jauh satelit yang paling sukses, mulai dari era Landsat hingga saat ini (Andrefouet et al., 2001). Zona geomorfologi ini diketahui berasosiasi dengan profil kedalaman dan struktur komunitas bentik tertentu (Andrefouet et al., 2001; Andrefouet dan Guzman, 2005).

Oleh karena zona tersebut menempati skala ruang hingga ratusan 
meter, maka keberadaannya dapat dideteksi secara spasial oleh satelit resolusi menengah seperti: Landsat TM, ETM+; SPOT-HRV, ASTER dan tentunya oleh satelit resolusi lebih tinggi seperti IKONOS dan Quickbird. Menurut Blanchon (2011) zona geomorfologi yang dapat dikenali dari citra satelit Quickbird antara lain gobah, gusung karang; rataan terumbu, bagian depan terumbu yang curam dan berhadapan langsung dengan gelombang, serta bagian terumbu yang agak landai dimana detritus terumbu terakumulasi. Garis pemisah antar zona ini adalah perbedaan slope. Pemisah gobah dan paparan terumbu adalah slope pasir. Reef crest menjadi batas antara rataan terumbu yang lebih tinggi dan terumbu depan yang lebih landai. Menurut Hochberg (2011) teknologi penginderaan jauh satelit menjadi alat yang potensial untuk mengkuantifikasi struktur komunitas karang dan sebarannya pada kawasan yang cukup luas. Teknologi ini merupakan yang paling efektif dari sisi biaya dalam hal mendapatkan data sinoptik struktur komunitas pada kawasan terumbu karang, dan merupakan satu-satunya alat yang dapat menyajikan data yang uniform secara global.

Banyaknya kelas habitat yang dikenali oleh penginderaan jauh bergantung pada beberapa faktor, seperti jenis wahana, sensor, kondisi atmosfer, kejernihan perairan dan kedalaman. Andréfouët et al. (2003) menggunakan citra Ikonos multispektral untuk memetakan habitat karang. Akurasi tematik yang diperolehnya berkurang secara linier dengan semakin kompleksnya habitat. Purkis (2005) memperoleh delapan kelas habitat perairan dangkal dari citra Ikonos dengan akurasi 69\%. Lyons et al. (2011) mendapatkan akurasi peta bentik dari Quickbird dalam kisaran 57-95\%, dan Vahtmäe et al. (2011) menghasilkan tujuh kelas bentik dari citra Quickbird dengan akurasi $62 \%$.

Faktor kedalaman yang mempengaruhi sidik spektral habitat dapat di-eliminasi dengan koreksi kolom air (Lyzenga, 1978; Lyzenga, 1981). Metode ini menghasilkan indeks dasar tak dipengaruhi kedalaman dan berhasil baik pada perairan dangkal yang jernih seperti di terumbu karang. Kelemahannya adalah nilai indeks tidak mewakili reflektansi objek dan sering menimbulkan problema untuk objek yang menempati spektrum kedalaman yang luas, sehingga terjadi bias dalam estimasi rasio koefisien atenuasi (Maritorena, 1996). Meskipun demikian, metode ini signifikan meningkatkan akurasi peta (Mumby et al., 1998). Metode ini efektif bila tipe substrat setiap piksel diidentifikasi dan ditentukan kedalamannya (Hedley dan Mumby, 2003).

Tujuan yang hendak dicapai dari penelitian ini adalah : 1). menghasilkan peta substrat dasar di gobah dari citra quickbird melalui kombinasi koreksi kolom air dan zona geomorfologi, dan 2) menguji akurasi tematik peta yang dihasilkan.

\section{METODOLOGI}

\subsection{Waktu dan Tempat}

Citra satelit Quickbird yang digunakan adalah liputan tanggal 28 September 2008, yang memiliki resolusi spasial 2,44 m. Survei lapangan dilakukan pada tanggal tanggal 13-17 Mei 2008, 22-26 Juli 2008 dan 4-8 Juni 2010 berlokasi di Karang Lebar, Kepulauan Seribu, Jakarta. Kegiatan lapangan mencakup penentuan tipe dasar perairan, penentuan posisi, pengamatan pasang surut dan pemeruman batimetri. Peralatan yang digunakan adalah mapsonder, GPS, camcorder, kamera digital, alat pengukur pasang surut, dan perahu.

\subsection{Konversi Nilai Digital Piksel ke Radiansi dan Koreksi Kolom Air}

Konversi citra Quickbird yang telah dikoreksi radiometrik ke nilai radiansi, ditentukan oleh tanggal liputan dan nilai bitnya. Nilai-nilai ini tersedia di dalam berkas metadata citra yang berekstensi *.IMD. Konversi ke radiansi spektral di pucuk atmosfer (top-of-atmosphere/TOA) berlangsung dalam dua tahap. Tahap pertama adalah konversi ke radiansi (Krause, 2003):

$$
L_{\text {Pixel,Band }}=\text { abscalFactor } r_{\text {Band }} \cdot q_{\text {PixelBand }}
$$

$L_{\text {Pixel,band }}$ adalah nilai radiansi piksel di TOA [ $\left.\mathrm{Wm}^{-2} \mathrm{sr}^{-1}\right]$, absCalFactor ${ }_{\text {Band }}$ adalah faktor kalibrasi radiometrik absolut [Wm 
${ }^{2} \mathrm{Sr}^{-1}$ satuan $^{-1}$ ] untuk kanal tersebut, dan $q_{\text {Pixel,Band }}$ adalah piksel yang terkoreksi radiometrik. Tahapan kedua adalah membagi radiansi dengan panjang gelombang efektif (Krause, 2003):

$L_{\lambda \text { Pixel,Band }}=\frac{L_{\text {Pixel,band }}}{\Delta \lambda_{\text {Band }}}$

$L_{\lambda \text { Pixel,Band }}$ adalah radiansi spektral TOA rerata kanal untuk piksel citra $\left[\mathrm{Wm}^{-2} \mathrm{sr}^{-}\right.$ $\left.{ }^{1} \mu \mathrm{m}^{-1}\right]$, dan $\Delta_{\lambda \text { Band }}$ adalah panjang gelombang efektif kanal yang bersangkutan.

Koreksi kolom air mengikuti metode Lyzenga (1978) yang dirinci langkah-langkahnya sebagai berikut (Green et al., 2000):
1) eliminasi sebaran cahaya di atmosfer dan pantulan dari permukaan air radiansi terkoreksi atmosfer $=L_{i}-L_{\text {si }}$ $\mathrm{Li}=$ radiansi piksel kanal i, Lsi=radiansi rata-rata laut dalam pada kanal i.

2) linierisasi hubungan kedalaman dan radiansi; $X_{i}=\ln \left(L_{i}\right)$

3) regresi radiansi substrat pada kedalaman yang berbeda-beda

$$
\begin{aligned}
& L_{i}=L_{s i}+a \cdot r \cdot e^{(-2 k j z)} \\
& a=\text { konstanta, } r=\text { reflektansi } \\
& \text { dasar, } z=\text { kedalaman dan } k= \\
& \text { koefisien attenuasi. }
\end{aligned}
$$

4) sebaran indeks dasar akan mengikuti garis lurus: $p=y-q \cdot x$, bila $q$ adalah gradien garis regresi $y$ pada $x$. $y=\ln \left(L_{i}\right), x=\ln \left(L_{j}\right)$,

maka :

$$
\text { kedalaman - indeks varian } \operatorname{vaj}_{i j}=\ln \left(L_{i}\right)-\left[\left(\frac{k_{i}}{k_{j}}\right) \cdot \ln \left(L_{j}\right)\right]
$$

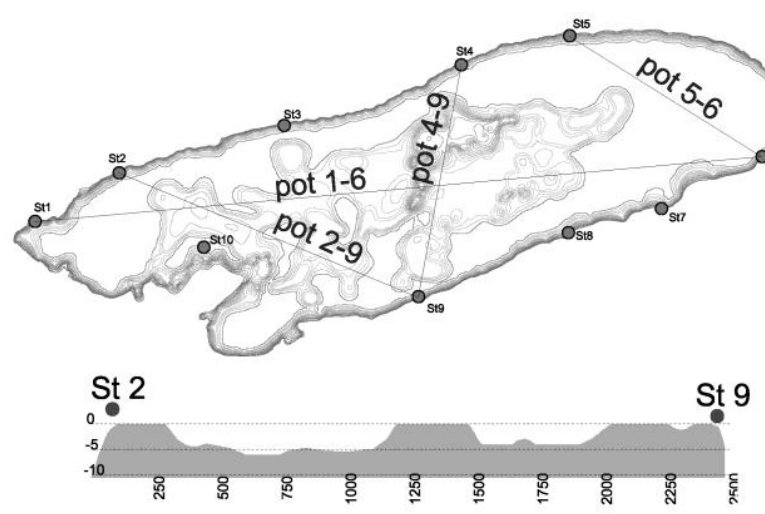

(a)

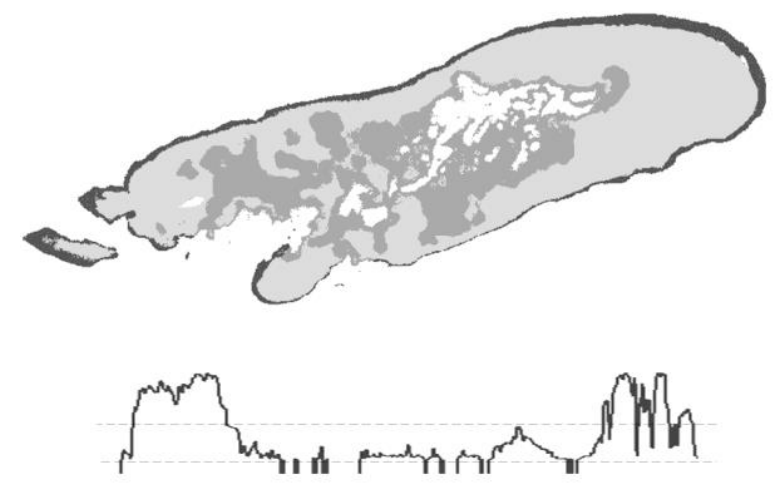

(b)

Gambar 1. a) Profil batimetri Karang Lebar; b) profil nilai piksel dari citra 
Setiap pasangan kanal spektral akan menghasilkan kanal baru yang nilai pikselnya tidak dipengaruhi kedalaman dan spesifik untuk satu jenis substrat.

\subsection{Profil Geomorfologi Gobah Karang Lebar}

Studi batimetri oleh Siregar et al. (2010) memperlihatkan bahwa profil melintang kedalaman Karang Lebar secara garis besar dapat dibagi menjadi 3 zona yaitu: zona gobah dengan kedalaman 10 hingga 14 meter, zona rataan pasir dengan kedalaman kurang dari 5 meter, dan zona tubir yang slopenya curam dan memiliki kedalaman lebih dari 14 meter (Gambar 1a). Profil melintang yang sama disadap dari kombinasi kanal citra Quickbird (Gambar 1b).

\subsection{Pengelompokan Substrat Dasar}

Pengelompokan substrat dilakukan berdasarkan nilai piksel dari tiga kanal Quickbird. Masing-masing tipe substrat yang ditelah ditentukan tipenya di lapangan diplot pada citra sesuai dengan posisinya. Nilai-nilai piksel untuk substrat tersebut kemudian disadap dari masing-masing kanal, dan dikelompokkan berdasarkan kemiripan Bray Curtis (Clarke dan Gorley, 2006):

$S=100\left(1-\frac{\sum_{i}\left|y_{i 1}-y_{i 2}\right|}{\sum_{i} y_{i 1}+\sum_{i} y_{i 2}}\right)$

$S$ adalah kemiripan Bray Curtis substrat 1 dan $2, y_{i 1}$ adalah nilai piksel pada kanal ke-i untuk substrat $1, y_{i 2}$ adalah nilai piksel kanal ke-i untuk substrat 2 .

\subsection{Uji Akurasi Tematik}

Matriks kesalahan tersusun dari senarai berukuran $\mathrm{n}$ kali $\mathrm{n}$, dimana $\mathrm{n}$ adalah banyaknya kelas objek yang ada di peta (Stehman, 1996; Congalton dan Green, 2009). Misalkan N piksel citra satelit diklasifikasikan kedalam $\mathrm{q}$ kategori. Dengan menyensus semua N piksel dan klasifikasi yang dianggap benar untuk setiap piksel, maka bentuk matrik kesalahan populasinya dapat disajikan seperti Tabel 1. Bila kelas-kelas pada citra merupakan strata dalam sampling stratifikasi, maka total baris $\mathrm{Nh}$ telah diketahui sementara total kolom tidak diketahui. Banyaknya data masukan Nhj juga belum diketahui. Nilai Kappa dihitung dengan rumus (Stehnan, 1996):

$K A P P A=\frac{\sum_{i=1}^{q} P_{i i}-\sum_{i=1}^{q} P_{i+} P_{+i}}{1-\sum_{i=1}^{q} P_{i+} P_{+i}}$

$P_{i i}=\frac{N_{i i}}{N}, P_{i+}=\frac{N_{i}}{N}, \operatorname{dan} P_{+i}=\frac{M_{i}}{N}$, kappa merupakan parameter populasi, sehingga tidak berubah dengan perbedaan desain sampling.

\section{HASIL DAN PEMBAHASAN}

Sejumlah 325 titik lapangan di Karang Lebar telah ditentukan tipe substratnya berdasarkan penilaian visual. Distribusi titik cek lapangan tersebut disajikan pada Gambar 2. Dari 325 titik cek lapangan tersebut, terdapat 16 tipe substrat dasar berbeda yang dapat dikenali oleh surveyor. Penilaian konsistensi surveyor dalam menentukan tipe substrat dilakukan dengan cara mengelompokkan nilai piksel substrat tersebut berdasarkan indeks kemiripan Bray Curtis (Gambar 3). Pengelompokan ini memperlihatkan bahwa pada indeks kemiripan Bray Curtis 90\%, hanya dikenali dua tipe substrat, yang dalam hal ini dipastikan sebagai tipe biotik dan abiotik. Bila indeks kemiripan di tingkatkan menjadi $90-95 \%$ maka diperoleh 3 tipe substrat dominan yaitu lamun dan karang (biotik) serta pasir (abiotik). Fakta dominasi substrat ini dipertegas oleh tampilan sidik spektral ketiga tipe substrat tersebut (Gambar 4a) yang dibandingkan dengan hasil studi Maeder et al. (2002) pada Gambar 4b.

Tabel 1. Matrik kesalahan

\begin{tabular}{|c|c|c|c|c|c|c|}
\hline & \multicolumn{4}{|c|}{ Lapangan } & \multirow{2}{*}{$\begin{array}{l}\text { Total } \\
\text { baris }\end{array}$} \\
\hline & & 1 & 2 & $\ldots$ & $\mathrm{q}$ & \\
\hline \multirow{4}{*}{$\stackrel{\sigma}{\leftrightarrows}$} & 1 & $\mathrm{~N} 11$ & N12 & $\ldots$ & $\mathrm{N} 1 \mathrm{q}$ & N1 \\
\hline & 2 & $\mathrm{~N} 21$ & N22 & $\ldots$ & $\mathrm{N} 2 \mathrm{q}$ & $\mathrm{N} 2$ \\
\hline & $:$ & : & $:$ & $\ldots$ & : & $:$ \\
\hline & $\mathrm{q}$ & $\mathrm{Nq} 1$ & $\mathrm{Nq} 2$ & $\ldots$ & Nqq & $\mathrm{Nq}$ \\
\hline
\end{tabular}



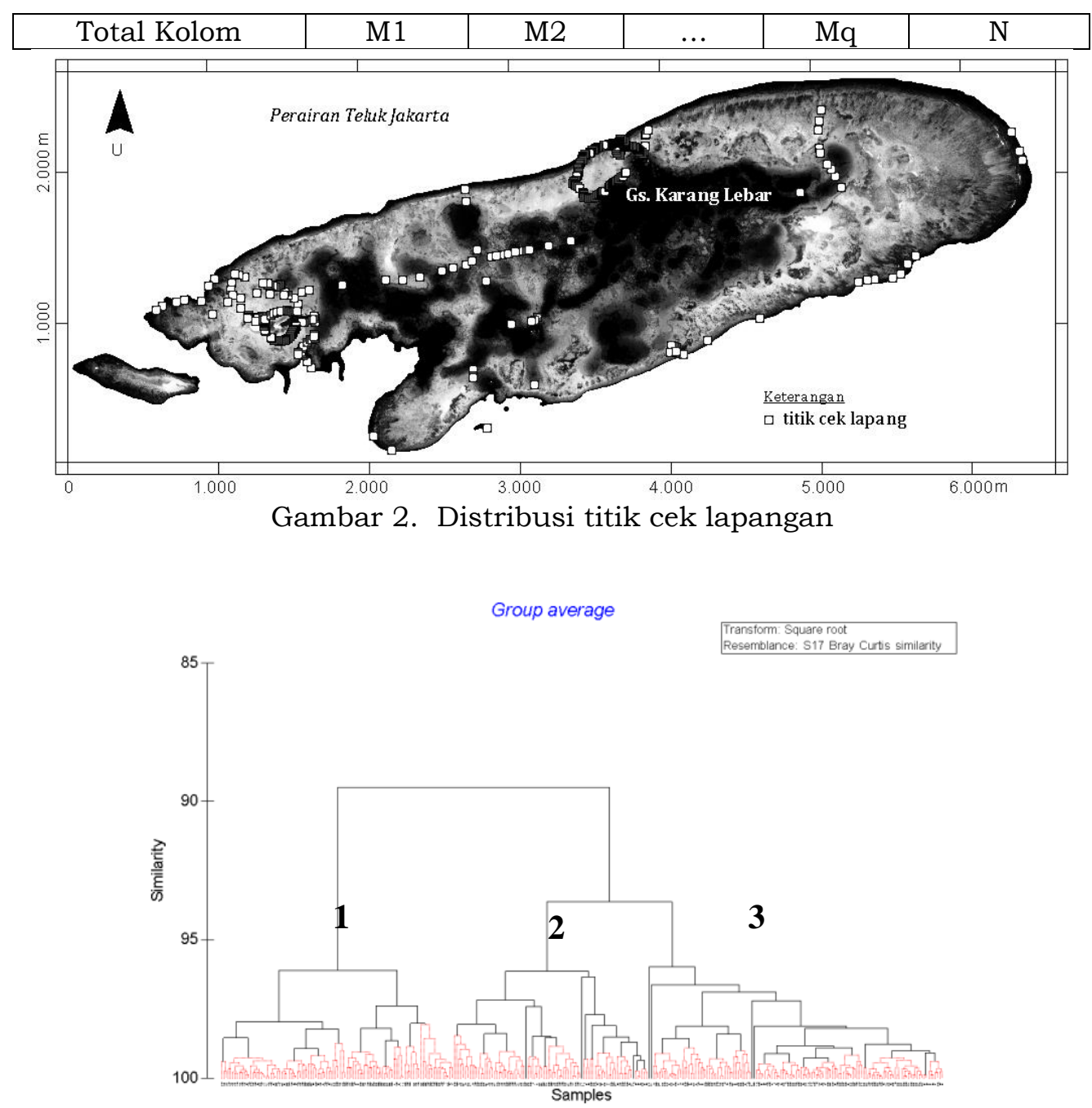

Gambar 3. Kemiripan Bray Curtis berdasarkan nilai piksel substrat lapangan

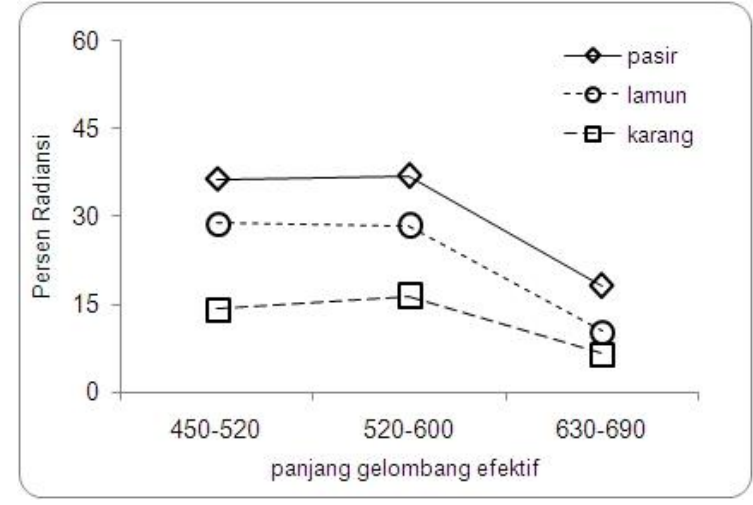

(a)

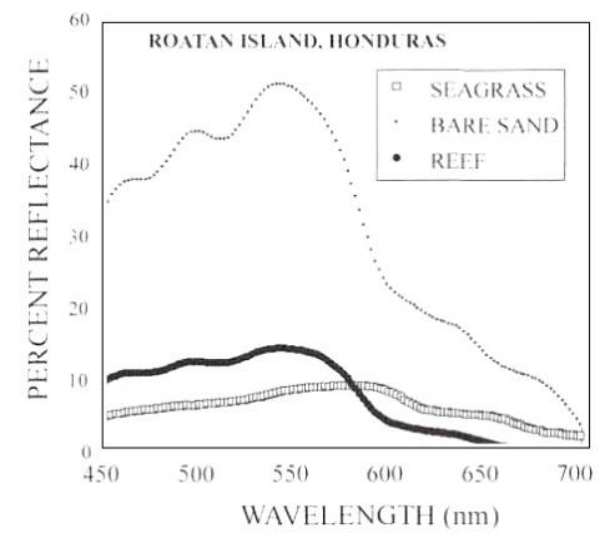

(b)

Gambar 4. Sidik spektral substrat dasar a) dari nilai radiansi piksel Quickbird b) dari pengukuran reflektansi di Honduras (Maeder et al., 2002)

Koreksi kolom air menghasilkan nilai indeks dasar yang spesifik untuk masing masing tipe substrat. Implementasi metode Lyzenga pada citra Quickbird Karang Lebar ini menghasilkan nilai batas indeks dasar untuk pasir adalah 0.415 dan lamun adalah 0.199 (Gambar 5a). Sementara nilai indeks dibawah 0.199 dapat ditetapkan sebagai tipe dasar karang. 
Batas-batas nilai ini kemudian dijadikan dasar untuk melakukan pengelompokan nilai dari histogram citra indeks dasar (Gambar 5b).

Dekomposisi spasial zona geomorfologi diperoleh dari gabungan citra Quickbird kanal 2 dan 3. Andrefouet dan Guzman (2005) menggunakan citra ETM kanal 2 (hijau) untuk mendelineasi karang tepi. Citra gabungan mula-mula disadap profil melintang nilai digitalnya, kemudian direklasifikasi sehingga diperoleh gambaran spasial zona geomorfologi di lokasi studi. Zona spasial geomorfologi ini digunakan sebagai mask dalam pemotongan nilai-nilai digital citra indeks dasar. Kombinasi ini menghasilkan beberapa berkas raster yaitu: citra dominan pasir di zona rataan terumbu dan gobah, citra dominan lamun di zona rataan terumbu dan tubir, citra dominan karang di gobah dan tubir (Gambar 6). Citra-citra yang mewakili substrat dominan pada zona geomorfologi ini kemudian digabungkan kembali untuk menggambarkan distribusi substrat di Karang Lebar (Gambar 7).

Uji akurasi peta substrat dasar di Karang Lebar yang dihasilkan dari metode kombinasi disajikan pada Tabel 1. Nilai kesalahan total yang diperoleh adalah mencapai $17,9 \%$ atau senilai dengan akurasi $82.1 \%$. Bila komponen dari masing-masing sel penyusun matriks kesalahan ikut diperhitungkan maka diperoleh nilai total kappa sebesar $68,8 \%$. Dengan jumlah titik lapangan yang lebih banyak, akurasi tematik yang dihasilkan ini lebih baik daripada yang dihasilkan oleh studi sebelumnya di lokasi yang sama (Siregar, 2010).

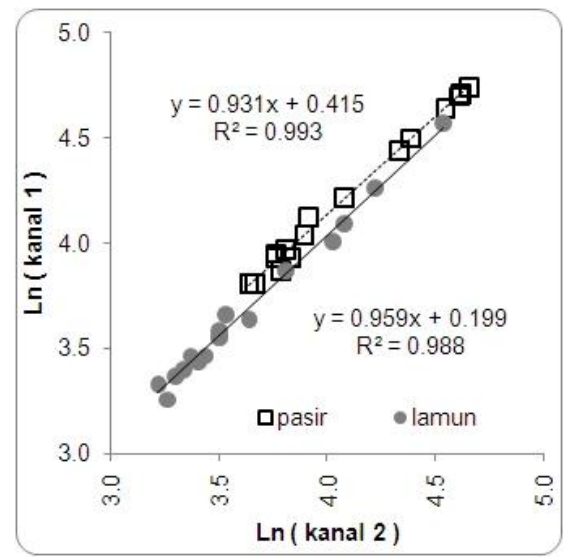

(a)

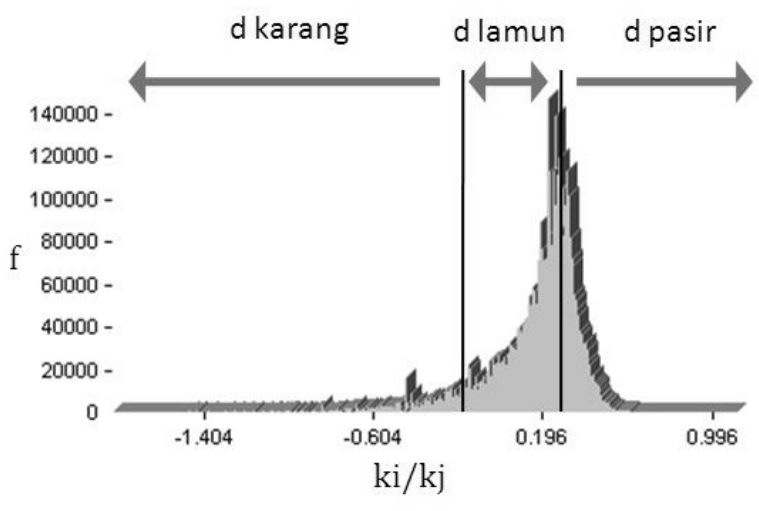

(b)

Gambar 5. a) Gabungan indeks substrat pasir dan lamun, dan b) nilai batas pemotongan dalam reklasifikasi citra indeks dasar

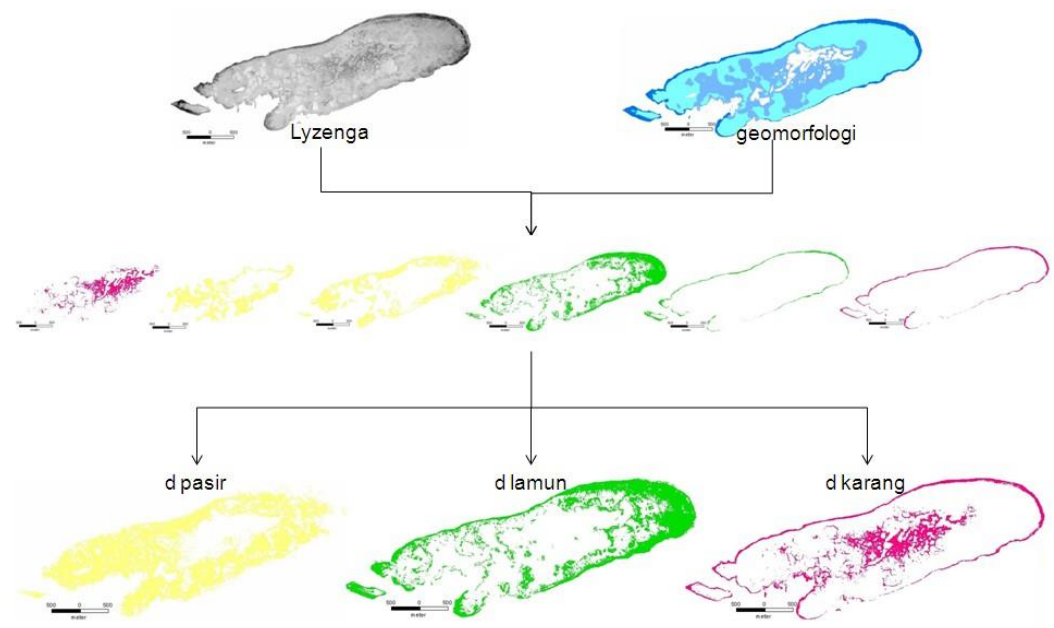

Gambar 6. Kombinasi citra indeks dasar dan zona geomorfologi untuk mendapatkan tipe dasar dominan di Gobah Karang Lebar 


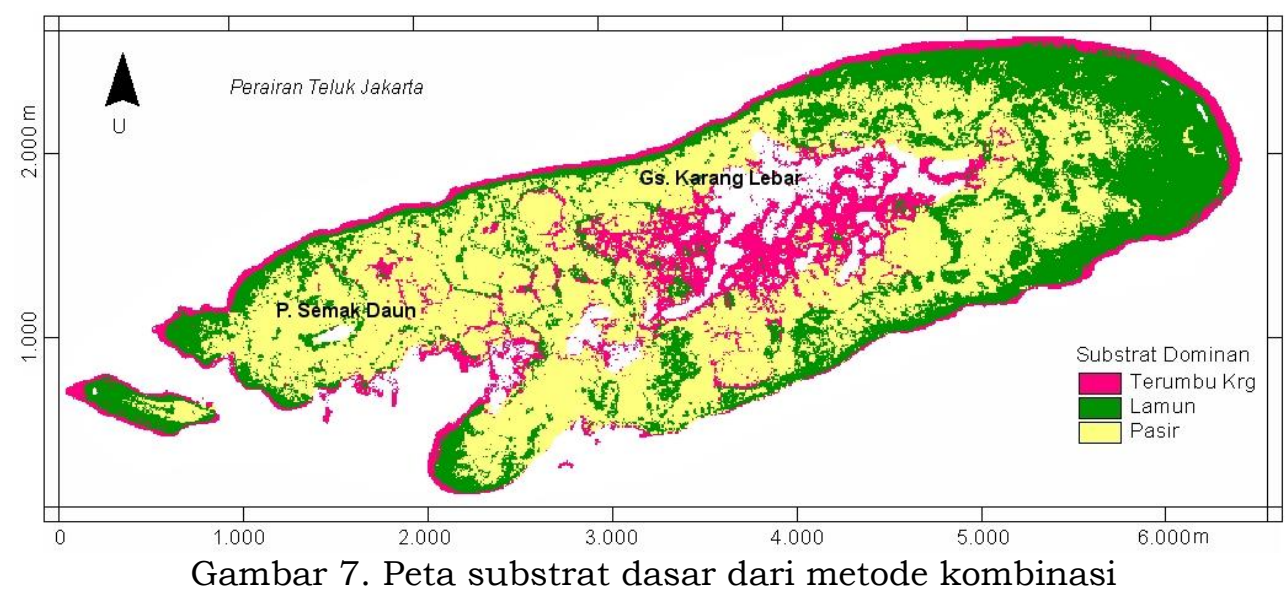

Tabel 1. Matrik kesalahan metode KAG

\begin{tabular}{|c|c|c|c|c|c|c|}
\hline & \multicolumn{6}{|c|}{ Lapangan } \\
\hline \multirow{6}{*}{$\stackrel{\Xi}{ \pm}$} & Tipe habitat & dlamun & dpasir & dkarang & $\Sigma$ baris & Error C \\
\hline & dlamun & 38 & 16 & 9 & 63 & 0.3968 \\
\hline & dpasir & 4 & 165 & 18 & 187 & 0.1176 \\
\hline & dkarang & 1 & 10 & 64 & 75 & 0.1467 \\
\hline & $\Sigma$ kolom & 43 & 191 & 91 & 325 & \\
\hline & Error O & 0.1163 & 0.1361 & 0.2967 & & $0.1785^{*}$ \\
\hline
\end{tabular}

${ }^{*} 95 \%$ Confidence Interval $=+/-0.0416 \quad(0.1368-0.2201)$

${ }^{*} 99 \%$ Confidence Interval $=+/-0.0548 \quad(0.1237-0.2333)$

Overall Kappa $=0.6878$

Citra Quickbird mengumpulkan informasi spektral substrat dari tiga kanal yaitu biru, hijau dan merah. Ketiga kanal ini memiliki penetrasi yang berbeda ke kolom perairan. Kanal biru diketahui memiliki penetrasi yang paling dalam dan merah merupakan kanal dengan penetrasi paling dangkal. Karakteristik ini dapat dimanfaatkan untuk membangun profil nilai digital dari zona-zona geomorfologi di Karang Lebar. Meskipun kanal biru faktanya memiliki penetrasi paling dalam, namun kanal ini juga yang paling banyak menerima efek hamburan dari atmosfer, sehingga pemilihan kanal hijau untuk mewakili kolom perairan yang lebih dalam dianggap lebih tepat.

Algoritma Lyzenga telah digunakan pada banyak studi pemetaan habitat karang diberbagai kondisi perairan dangkal (Lyzenga, 1978; Mumby et al., 1998; Stumpf et al., 2003; Lyons et al., 2011). Sebelum algoritma digunakan, perbandingan koefisien atenuasi harus dibangun dari hubungan substrat dengan berbagai kedalaman pada minimal dua kanal berbeda. Meskipun demikian, algoritma ini tidak dapat mengakomodasi variasi albedo untuk seluruh substrat lamun (Lyons et al. 2011) dan membatasi kemampuan sensor untuk deteksi yang lebih detail (Vahtmäe, et al., 2011). Salah satu upaya untuk meningkatkan akurasi citra substrat dari metode koreksi kolom air adalah dengan kembali memilah-milah tipe substrat tersebut berdasarkan kelompok kedalamannya. Dalam hal ini kelompok kedalaman dapat dianggap berasosiasi dengan suatu zona geomorfologi (Andrefouet dan Guzman, 2005; Blanchon, 2011).

Hasil-hasil ini memperlihatkan bahwa meskipun di lapangan secara visual surveyor dapat membedakan sejumlah besar tipe substrat (dalam hal ini 16), namun implementasinya ke citra masih terkendala dengan rendahnya kemampuan kanal-kanal untuk memisahkan karakter objek. Meskipun demikian, pemanfaatan penginderaan jauh satelit dapat lebih ditekankan pada aspek perluasan wilayah studi, sehingga dapat mengisi kekosongan data yang terabaikan oleh sampling insitu (Fearns, et al., 2011) 


\section{KESIMPULAN}

Peta substrat dasar di gobah Karang Lebar dapat menyajikan tiga tipe substrat dominan yaitu lamun, karang (biotik) dan pasir (abiotik) pada indeks similaritas Bray Curtis 90-95\%. Kombinasi zonasi geomorfologi dan koreksi kolom air menghasilkan peta substrat dasar dengan akurasi tematik dan kappa total masing-masing $82.1 \%$ dan $68,8 \%$. Metode kombinasi cukup akurat untuk dijadikan dasar bagi pembuatan peta substrat dasar di perairan gobah.

\section{DAFTAR PUSTAKA}

Andréfouëta, S., F.E. Muller-Karger, E.J. Hochberg, C. Hu dan K.L. Carder. 2001. Change Detection in Shallow Coral Reef Environments using Landsat 7 ETM+ Data. Remote Sensing of Environment 78. Hal:150-162.

Andréfouëta, S., P. Kramer, D.T.-Pulliza, K.E. Joyce, E.J. Hochberg, R.GPérezf, P.J. Mumby, B. Riegl, H. Yamano, W.H. White, M. Zubia, J.C. Brock, S.R. Phinn, A. Naseer, B.G. Hatcher, F.E. Muller-Karger. 2003. Multi-site evaluation of IKONOS data for classification of tropical coral reef environments. Remote Sensing of Environment 88. Hal: 128-143.

Andrefouet, S dan H.M. Guzman. 2005. Coral reef distribution, status and geomorphology-biodiversity relationship in Kuna Yala (San Blas) archipelago, Caribbean Panama. Coral Reef. Vol 24. Hal:3142.

Blanchon, P. 2011. Geomorphic Zonation. Di dalam: David H, editor. Encyclopedia of Modern Coral Reefs. Springer Science + Business Media B.V. Hal: 469-483.

Clarke, K.R dan R.N., Gorley. 2006. PRIMER v6: User Manual/Tutorial. PRIMER-E, Plymouth. Hal:43-67.

Congalton, R.G dan K. Green. 2009. Assessing The Accuracy of Remotely Sensed Data: Principles and Practices. CRC Press, Inc. Florida. 130 hal.

Eakin, C.M., C.J. Nim, R.E. Brainard, C. Aubrecht, C. Elvidge, D.K. Gledhill,
F. Muller-Karger,P.J. Mumby, W.J. Skirving, A.E. Strong, M. Wang, S. Weeks, F. Wentz, dan D. Ziskin. 2010. Monitoring coral reefs from space. Oceanography.Vol. 23 No. 4. Hal: 118-133.

Fearns, P.R.C., W.Klonowski, R.C.Babcock, P.England dan J.Phillips. 2011. Shallow water substrate mapping using hyperspectral remote sensing. Continental Shelf Research. Vol:31. Hal:1249-1259.

Green, E.P.; Mumby, P.J.; Edwards, A.J.; Clark, C.D. 2000. Remote Sensing Handbook for Tropical Coastal Management; UNESCO: Paris, France. 316 hal.

Hedley, J.D and P. J., Mumby. 2003. A remote sensing method for resolving depth and subpixel composition of aquatic benthos. Limnol. Oceanogr., vol 48 (1, part 2), . hal: 480-488.

Hochberg, E.J. 2011.Remote Sensing of Coral Reef Processes. Didalam: Zvy, D dan Noga, S, editor. Coral Reefs: An Ecosystem in Transition. Springer Science + Business Media B.V.Hal: 25-33.

Knudby, A., C. Roelfsema, M. Lyons, S. Phinn dan S. Jupiter. Mapping Fish Community Variables by Integrating Field and Satellite Data, Object-Based Image Analysis and Modeling in a Traditional Fijian Fisheries Management Area Remote Sens. Vol. 3. Hal: 460-483Krause, 2003).

Krause, K. 2003. Radiance Conversion of QuickBird Data : Technical Note. DigitalGlobe. 4 hal.

Lyons, M., S. Phinn dan C. Roelfsema. 2011. Integrating Quickbird MultiSpectral Satellite and Field Data: Mapping Bathymetry, Seagrass Cover, Seagrass Species and Change in Moreton Bay, Australia in 2004 and 2007. Remote Sens. vol 3. Hal: 42-64.

Lyzenga, D.R.1978. Passive Remote Sensing Techniques for Mapping Water Depth and Bottom Features. Applied Optics. Vol.17, No.3. hal: 379-383.

Lyzenga, D.R.1981. Remote Sensing of Bottom Reflectance and Water Attenuation Parameters in Shallow Water Using Aircraft and Landsat 
Data. Int. J. Remote Sensing. Vol. 2. No.1. Hal:71-82.

Maeder, J., S. Narumalani, D.C. Rundquist, R.L. Perk, J. Schalles, K. Hutchins, dan J. Keck. 2002. Classifying and Mapping General Coral-Reef Structure Using Ikonos Data. Photogrammetric Engineering $\&$ Remote Sensing. Vol. 68, No. 12, hal: 1297-1305.

Maritorena, S. 1996. Remote sensing of the water attenuation in coral reefs: a case study in French Polynesia. Int. J. Remote Sensing.Vol. 17, No. 1, hal: 155-166.

Meaden, G.J., J.M. Kapetsky. 1991.Geographical information systems and remote sensing in inland bsheries and aquaculture. FAO Fisheries Techn Pap 318. 262 hal.

Mumby, P. J., C. D. Clark, E. P. Green dan A. J. Edwards. 1998. Benefits of water column correction and contextual editing for mapping coral reefs. Int. J. Remote Sensing, Vol. 19, No. 1, hal: $203-210$.

Purkis, S.J.2005. A Reef Up Approach to Classifying Coral Habitat From IKONOS Imagery. IEEE Transactions on Geoscience and Remote Sensing, Vol.43, No.6, hal:1375-1390.
Siregar, V. 2010. Pemetaan Substrat Dasar Perairan Dangkal Karang Congkak dan Lebar Kepulauan Seribu Menggunakan Citra Satelit Quickbird. E-Jurnal Ilmu dan Teknologi Kelautan Tropis. Vol. 2, No.1. Hal: 19-30.

Siregar, V., S. Wouthuyzen, S. Sukimin, S.B. Agus, M.B. Selamat, Adriani, Sriati, A.A. Muzaki. 2010. Informasi Spasial Habitat Perairan Dangkal dan Pendugaan Stok Ikan Terumbu Menggunakan Citra Satelit. Southeast Asian Regional Centre for Tropical Biology dan Fakultas Perikanan dan Ilmu Kelautan Institut Pertanian Bogor. Hal: 5-8.

Stehman, S.V. 1996. Estimating The Kappa Coefficient and Its Variance under Stratified Random Sampling. Photogrammetric Engineering \& Remote Sensing, vol. 62, No.4, hal: 401-405.

Stumpf, R.P., K. Holderied dan M. Sinclair. 2003. Determination of water depth with high-resolution satellite imagery over variable bottom types. Limnol. Oceanogr., 48(1, part 2), 547-556.

Vahtmäe, E., T. Kutser, J. Kotta, dan M. Pärnoja. 2011. Detecting patterns and changes in a complex benthic environment of the Baltic Sea. Journal of Applied Remote Sensing. Vol 5, 18 hal. 